\title{
Analisis Konten Buku Teks IPA Terpadu Kelas VIII Semester 1 Ditinjau Dari Aspek Literasi Saintifik
}

\author{
Mutia Risma, Rahmayani, Fitria Handayani \\ ${ }^{1)}$ Program Studi Magister Pendidikan Fisika Pascasarjana Universitas Negeri Padang \\ mutiarisma10@gmail.com ${ }^{1)}$ rahmayanifisika12@gmail.com ${ }^{2)}$ handayanifitria@gmail.com ${ }^{3)}$
}

\begin{abstract}
Science learning has an important role for students to understand natural phenomena with scientific methods. Science learning is taught in an integrated manner and contains literacy in it. Skills in literacy are needed to help students understand learning resources. One type of literacy is scientific literacy. Scientific literacy is the ability to understand or get involved with science issues and ideas around the environment. Scientific literacy consists of four aspects, namely 1) the scientific context, 2) the scientific process, 3) the scientific concept and 4) the scientific attitude. This research is a descriptive research that contains a description of the object under research. The object of this research is the integrated science textbook for grade VIII in junior high school. The instrument used in the form of a questionnaire assessment of integrated science textbooks related to scientific literacy aspects. The results showed that, among the five textbooks researched, the best book reviewed in terms of the scientific context and the scientific process was book D with grades of 78.6 and 78.1, respectively. In terms of scientific concepts, the best integrated science textbooks are books A and D with a value of 82.1. Meanwhile, the integrated science textbook that is good to use is seen from the aspect of scientific attitude is book E with a value of 75. After processing the data, it is found that the best book used to improve students' scientific literacy ability is book D with a value of 77.4.
\end{abstract}

Keywords : Content analysis, Textbook, Integrated science, Scientific literacy,

(i) his is an open access article distributed under the Creative Commons 4.0 Attribution License, which permits unrestricted use, distribution, and reproduction in any medium, provided the original work is properly cited. $\odot 2018$ by author and Universitas Negeri Padang.

\section{PENDAHULUAN}

Pendidikan merupakan upaya terencana dalam membentuk manusia yang berkarakter dan berkualitas, salah satunya adalah melalui pembelajaran IPA (Ilmu Pengetahuan Alam). Menurut Asrizal, et al (2017), berdasarkan karakteristik IPA, sebaiknya pembelajaran IPA dilakukan secara terpadu sebagaimana tuntutan kurikulum 2013. Pembelajaran IPA berperan penting dalam membantu mengarahkan peserta didik untuk berpikir dan memahami fenomena alam dengan metode ilmiah seperti yang dilakukan oleh ilmuwan (NRC, 1996). Metode ilmiah yang dimaksud adalah pembelajaran yang menerapkan langkah-langkah ilmiah dalam pemecahan masalah. Menurut RTI (2014), dalam proses pembelajaran, keterampilan dalam literasi sangat diperlukan untuk membantu peserta didik dalam memahami sumber belajar, baik teks lisan, tulisan ataupun visual. Salah satu jenis literasi adalah literasi saintifik.

Literasi saintifik sangat penting dalam memecahkan berbagai persoalan yang terkait dengan etika, moral dan isu-isu global karena adanya perubahan yang terjadi dalam bidang sains dan teknologi. Penilaian literasi tidak hanya pada pengukuran tingkat pemahaman pengetahuan IPA, akan tetapi juga pemahaman terhadap berbagai proses IPA dan kemampuan mengaplikasikan pengetahuan dan proses IPA dalam situasi yang nyata. Berbagai upaya telah banyak dilakukan untuk mewujudkan masyarakat berliterasi saintifik, salah satunya melalui kurikulum dan pembelajaran (Anjarsari, 2014).

Upaya untuk meningkatkan mutu pendidikan selalu dilakukan oleh pemerintah ataupun swasta baik itu melalui pengadaan buku ajar ataupun penyempurnaan kurikulum (Festiyed, 2014). Indonesia telah melakukan penyempurnaan dari kurikulum KTSP menjadi kurikulum 2013. Kurikulum 2013 menuntut terlaksananya literasi saintifik dalam pembelajaran. Hal ini dimaksudkan agar peserta didik memperoleh pengalaman yang lebih bermakna.

Namun kenyataan yang terjadi ialah peserta didik Indonesia memiliki kemampuan literasi saintifik yang sangat rendah. Programme for International Student Assessment (PISA) melakukan beberapa kali survei terhadap kemampuan peserta didik di berbagai negara terkait literasi saintifik. Hasil survei yang dil- 
akukan pada tahun 2000 menunjukkan bahwa Indonesia menempati urutan ke 38 dari 41 negara dengan nilai yang diperoleh sebesar 393 . Survei ini terus dilakukan pada tahun berikutnya dengan hasil-hasil sebagai berikut. Indonesia memperoleh peringkat 38 dari 40 negara ditinjau dari prestasi literasi saintifik peserta didik, dimana nilai yang diperoleh adalah 395. Pada tahun 2006 diperoleh nilai 393, Indonesia menempati urutan ke 50 dari 57 negara. Selanjutnya tahun 2012 Indonesia menempati urutan ke 64 dari 65 negara dan memperoleh nilai 382. Survei terakhir yaitu pada tahun 2015 yang mana Indonesia memperoleh nilai 403 dan urutan ke 62 dari 70 negara (OECD, 2015). Berdasarkan hasil PISA yang telah dijelaskan dapat diungkapkan bahwa literasi saintifik peserta didik Indonesia selalu menempati posisi 10 besar terbawah dibanding dengan negara lain.

Dari hasil survei tersebut dapat diuraikan bahwa peserta didik Indonesia secara keseluruhan hanya dapat mengetahui fakta mendasar dan belum bisa menyampaikan serta menghubungkan kemampuan yang dimilikinya dengan topik sains lainnya. Selain itu, mereka juga belum mampu menerapkan konsep-konsep yang dimilikinya dengan baik (Toharudin, 2011). Sejalan dengan hal itu, Fatmawati dan Utari (2015) menyatakan ada tiga masalah yang dapat menyebabkan rendahnya literasi saintifik peserta didik di Indonesia.

Pertama, peserta didik tidak memahami kejadian ilmiah yang terjadi dalam kehidupan sehari-hari, terutama pada awal pembelajaran. Akibatnya, peserta didik tidak berkesempatan untuk mengadakan inferensi terhadap kejadian ilmiah tersebut. Kedua, pembelajaran yang dilakukan cenderung tidak melibatkan peserta didik dalam percobaan/praktikum sehingga pembelajaran menjadi kurang bermakna. Hal ini menyebabkan peserta didik memiliki kemampuan yang rendah dalam merancang penyelidikan ilmiah dan mengidentifikasi variabel-variabel penyelidikan. Selain itu, proses pembelajaran lebih menekankan pada tujuan pembelajaran dengan menuntaskan materi tepat waktu, bukan pada pro ses pembelajaran. Ketiga, saat menyimpulkan materi pembelajaran, pendidik belum mengarahkan peserta didik untuk menyimpulkan berdasarkan pada data maupun fakta yang ada, namun kesimpulan ini hanya berasal dari proses membaca buku. Hal ini berakibat pada kurangnya kemampuan peserta didik dalam membangun pengetahuan sendiri karena pendidik kurang menekankan pada pentingnya pengetahuan epistemik bagi peserta didik.

Beberapa faktor lain yang diduga menyebabkan rendahnya literasi saintifik peserta didik Indonesia yang berkaitan dengan proses pendidikan diantaranya adalah proses pembelajaran dan sumber belajar. Suastra (2010) menyatakan bahwa pembelajaran yang terjadi saat ini kurang memanfaatkan lingkungan sekitar peserta didik sebagai sumber belajar, sehingga peserta didik mengalami kesulitan untuk menghubungkan konsep sains yang dimilikinya dengan kehidupan sehari-hari. Selain itu, sumber belajar yang digunakan dalam proses pembelajaran kurang bervariasi, sehingga peserta didik hanya terfokus pada buku ajar yang menjadi pegangan pendidik pada saat mengajar (Festiyed, 2015). Ini berarti bahwa sumber belajar merupakan salah satu faktor yang kemampuan literasi saintifik peserta didik.

Salah satu sumber belajar adalah buku ajar. Buku ajar memiliki peranan penting dalam pembelajaran sains (Chiappetta et al., 1991). Selajan dengan pendapat tersebut, Asrizal, et al (2018) mengemukakan bahwa buku ajar merupakan salah satu bagian penting dalam proses pembelajaran. Pendidik dapat menggunakan buku ajar untuk memudahkan peserta didik dalam mempelajari materi tertentu.

Pemilihan buku ajar yang tepat merupakan salah satu hal yang dapat menentukan keberhasilan dalam proses pembelajaran. Untuk itu, sebelum digunakan, pendidik dan peserta didik hendaknya mengetahui buku ajar mana yang cocok digunakan untuk mendukung pembelajaran dengan literasi saintifik. Bersesuaian dengan hal tersebut, Rusilowati (2014) mengatakan bahwa pemilihan buku ajar harus sesuai dan tepat agar buku ajar tersebut dapat meningkatkan pemahaman sains peserta didik yang pada akhirnya diharapkan dapat juga meningkatkan literasi saintifik pada peserta didik. Pendapat tersebut didukung oleh Retno, et al (2017) yang mengungkapkan bahwa apabila bahan ajar yang digunakan berkualitas tinggi maka manfaat yang diperoleh akan lebih banyak. Peserta didik tidak hanya dapat meningkatkan kemampuan literasi sainsnya, akan tetapi juga dapat meningkatkan motivasi belajar, terutama dalam mata pelajaran IPA.

Bertitik tolak dari keadaan yang diharapkan dan keadaan sebenarnya yang telah dijelaskan, didapati adanya permasalahan dalam pembelajaran IPA. Salah satu solusi untuk meng 
atasi masalah ini adalah dengan menganalisis buku teks IPA terpadu yang digunakan dalam pembelajaran IPA, ditinjau dari aspek literasi saintifik. Hasil analisis diharapkan mampu memudahkan pendidik dan peserta didik dalam memilih buku teks IPA terpadu yang cocok digunakan untuk mendukung peserta didik dalam meningkatkan kemampuan literasi saintifik.

Sebelumnya, penelitian yang bertujuan untuk menganalisis buku teks terkait aspek literasi saintifik sudah pernah dilakukan oleh beberapa peneliti lainnya. Diantara peneliti tersebut adalah Nasution pada tahun 2018 dan Kurnia pada tahun 2014. Kurnia melakukan analisis pada dua buku, sedangkan Nasution menganalisis tiga buku. Kedua analisis ini memuat kategori literasi saintifik yang berbeda dengan aspek literasi saintifik pada PISA (2015). Kategori tersebut yaitu: 1) pengetahuan sains, 2) sains untuk menyelidiki, 3) sains sebagai cara berfikir dan 4) interaksi sains, teknologi dan masyarakat. Dari hasil dari kedua penelitian ini da-pat dijelaskan bahwa buku dominan memuat aspek proses saja. Artinya, penelitian ini masih belum bisa dirujuk oleh peserta didik untuk memilih buku mana yang baik digunakan.

Berbeda dengan dua penelitian sebelumnya, pada penelitian ini dianalisis lima buku teks dengan indikator yang mengacu pada kerangka PISA (2015). Aspek literasi saintifik dianalisis secara keseluruhan pada keempat aspeknya. Ini berarti bahwa hasil yang didapatkan dari penelitian yang dilakukan juga lebih menyeluruh. Pada hasil penelitian dapat dilihat bahwa kelima buku yang dianalisis memuat keseluruhan aspek literasi saintifik, sehingga dapat membantu pendidik maupun peserta didik dalam memilih buku mana yang paling baik digunakan diantara lima buku yang telah dianalisis. Ini berarti pula bahwa kesimpulan yang diperoleh lebih akurat dan bermanfaat bagi pendidik maupun peserta didik.

Dari solusi yang dijelaskan, terdapat dua kajian teori yang harus dikaji. Kajian teori pertama adalah buku teks IPA terpadu. Buku teks IPA terpadu disusun untuk mendukung proses pembelajaran IPA. Sesuai dengan rancangan kurikulum di SMP, pembelajaran IPA harus diajarkan secara terpadu. Keterpaduan dalam IPA dapat membantu siswa untuk memperoleh penguatan suatu pemahaman dari peran dan fungsi IPA dalam kehidupan sehari-hari dan dunia dimana mereka hidup (Asrizal et al, 2017).
Buku teks ialah sumber informasi dalam proses pembelajaran yang tidak dapat dipisahkan dari proses belajar dan mengajar di sekolah. Nugroho, et al (2017) mengatakan buku teks memiliki peran penting sehingga diharapkan memiliki kualitas yang baik dan memenuhi kriteria standar tertentu. Menurut Azhar (2003) buku teks yang baik adalah buku teks yang memperhatikan beberapa hal sebagai berikut: buku teks memuat stimulus yang sesuai baik secara visual maupun audio, mengakomodasikan respons peserta didik secara tepat, adanya umpan balik antara peserta didik dengan pendidik, serta pemilihan media yang tepat untuk menyajikan informasi atau stimulus untuk latihan-latihan dan tes. Sejalan dengan pendapat tersebut, Tarigan (2009) menyatakan bahwa buku teks berfungsi sebagai bahan belajar yang dalam penyusunannya harus sesuai dengan kurikulum yang berlaku, sehingga dapat digunakan dalam pembelajaran. Dari pendapat tersebut dapat disimpulkan bahwa buku teks merupakan salah satu sumber belajar yang menyajikan berbagai informasi bagi peserta didik dalam proses pembelajaran dan sesuai dengan kurikulum yang berlaku.

Kajian teori kedua berkaitan dengan literasi saintifik. DeBoer (2000) menyatakan bahwa istilah literasi saintifik pertama kali digunakan oleh Paul de Hart Hurt yang berasal dari Uni versitas Stanford. Literasi saintifik merupakan kemampuan untuk memahami ataupun ikut terlibat dengan isu-isu dan gagasangagasan sains di sekitar lingkungan. Menurut kerangka PISA (2015), literasi saintifik terdiri dari empat aspek yang saling terkait. Empat aspek tersebut yaitu aspek konteks saintifik, konsep saintifik, proses saintifik, dan sikap saintifik.

Aspek konteks saintifik merupakan aspek yang menuntut pemahaman sains dan teknologi tentang isu-isu personal, lokal maupun global baik yang terjadi saat ini maupun dimasa lalu. Berdasarkan PISA (2015), konteks saintifik dibagi menjadi tiga bidang yaitu bidang kehidupan dan kesehatan, bumi dan lingkungan, serta yang terakhir adalah bidang teknologi. Kemudian dari konteks tersebut dikembangkan lagi oleh OECD (2016) menjadi lima bidang yaitu bidang kesehatan dan penyakit, sumber daya alam, kualitas lingkungan, bahaya, serta bidang pembatas ilmu pengetahuan dan teknologi.

Aspek kedua dari literasi saintifik yaitu proses saintifik. Proses saintifik berkaitan 
dengan kemampuan untuk menjelaskan feno mena ilmiah, mengevaluasi dan merancang penyelidikan secara ilmiah serta menafsirkan data dan bukti ilmiah. Nofiana dan Julianto (2017) mengatakan bahwa proses sains melibatkan proses mental ketika menjawab pertanyaan atau memecahkan masalah misalnya menginterpretasikan bukti serta menarik kesimpulan. Menurut OECD (2016) aspek proses meliputi tiga kompetensi yang mendukung aspek proses, yaitu pengetahuan konten, prosedural dan epistemik.

Selanjutnya, aspek ketiga dari literasi saintifik yaitu konsep saintifik. Aspek ini bekait an dengan pemahaman mengenai fakta, konsep dan teori penjelasan utama yang membentuk dasar pengetahuan ilmiah. Menurut PISA (2015) aspek konsep terdiri dari tiga langkah. Langkah tersebut adalah menjelaskan fenomena ilmiah, mengevaluasi dan merancang penyelidikan ilmiah, serta menafsirkan data dan bukti ilmiah.

Aspek terakhir dari literasi saintifik adalah sikap saintifik. Sikap saintifik merupakan tanggapan mengenai fenomena ilmiah yang diamati peserta didik dan dapat memotivasinya dalam menyelesaikan persoalan sains (Wulandari \& Sholihin, 2015). Aspek ini berkaitan dengan seperangkat sikap terhadap sains yang ditunjukkan dengan ketertarikan terhadap sains dan teknologi, menilai pendekatan ilmiah yang tepat untuk suatu penyelidikan serta kesadaran terhadap masalah lingkungan. Menurut OECD (2016) sikap merupakan evaluasi peserta didik terhadap ilmu pengetahuan dalam tiga bidang, yaitu minat sains, menilai pendekatan ilmiah dan kesadaran terhadap lingkungan.

Bertitik tolak dari latar belakang masalah yang telah dikemukakan, analisis terhadap buku teks IPA terpadu perlu dilakukan. Hal ini diharapkan dapat mempermudah pendidik dan peserta didik dalam memilih butu teks IPA terpadu yang bermuatan literasi saintifik. Penelitian ini bertujuan untuk mendeskripsikan aspek-aspek literasi saintifik yang terdapat pada buku teks IPA terpadu di kelas VIII semester 1.

\section{METODE PENELITIAN}

Penelitian ini merupakan metoda peneliti an deskriptif, yaitu data yang dianalisis tidak untuk menolak maupun menerima hipotesis, melainkan hasil analisis ini merupakan gambaran dari objek yang dianalisis. Objek yang dianalisis pada penelitian ini adalah buku teks IPA terpadu kelas VIII semester 1, yang ber- jumlah lima dan merupakan buku kurikulum 2013. Adapun instrumen yang digunakan berupa angket penilaian buku teks IPA terpadu pada aspek literasi saintifik.

Data yang dikumpulkan melalui instrumen kemudian dianalisis menggunakan skala Likert. Pada skala Likert, setiap variabel yang akan diukur terlebih dahulu dijabarkan menjadi beberapa indikator yang dibuat dalam bentuk pertanyaan atau pernyataan dan nantinya dapat diukur serta diisi oleh penilai. Adapun rumus yang dapat digunakan untuk mengolah data adalah sebagai berikut.

Keterangan:

$$
P=\frac{F}{N} \times 100 \%
$$

$\mathrm{P}=$ Persentase hasil

$\mathrm{F}=$ Jumlah skor yang diperoleh

$\mathrm{N}=$ Jumlah skor tertinggi

Data dalam penelitian ini disajikan dalam bentuk grafik disertai dengan interpretasi dari grafik tersebut. Selanjutnya, data yang telah diolah dan dituangkan dalam bentuk grafik harus dianalisis kembali agar mudah dipahami. Grafik dapat dianalisis dengan mengkategorikannya berdasarkan Tabel 1 .

Tabel 1. Kategori Tingkat Literasi Saintifik Buku Teks IPA Terpadu Kelas VIII Semester 1

\begin{tabular}{ccc}
\hline No & Nilai & Kategori \\
\hline $\mathbf{1}$ & $0-20$ & Tidak baik \\
$\mathbf{2}$ & $21-40$ & Kurang baik \\
$\mathbf{3}$ & $41-60$ & Cukup baik \\
$\mathbf{4}$ & $61-80$ & Baik \\
$\mathbf{5}$ & $81-100$ & Sangat baik \\
\hline
\end{tabular}

(Riduwan, 2012)

Dari Tabel 1 dapat diuraikan bahwa buku teks IPA terpadu yang memperoleh nilai 0 sampai 20 dapat dikategorikan tidak baik dari aspek literasi saintifik. Buku yang memperoleh nilai 21 sampai 40 dikategorikan kurang baik, sedangkan yang memperoleh nilai 41 hingga 60 dikategorikan cukup baik. Selanjutnya, buku yang dapat dikategorikan baik ditinjau dari aspek literasi saintifik adalah buku yang mendapatkan nilai antara 61 sampai 80, sementara yang dikategori-kan sangat baik harus mendapatkan nilai antara 81 sampai 100.

\section{HASIL DAN PEMBAHASAN}

\section{Hasil Penelitian}


Hasil dari penelitian ini berupa hasil analisis buku teks IPA terpadu pada aspek literasi saintifik. Buku yang dianalisis dalam penelitian ini berjumlah lima buku. Kelima buku teks yang dianalisis merupakan buku kurikulum 2013 untuk pembelajaran IPA terpadu di kelas VIII semester 1 .

Teknik analisis data yang digunakan untuk menganalisis aspek literasi saintifik adalah analisis dokumen. Adapun instrumen yang digunakan untuk menganalisis ada tidaknya aspek literasi saintifik pada buku teks IPA terpadu adalah lembar penilaian dokumen, yang dalam hal ini adalah lembar penilaian buku teks IPA terpadu kelas VIII semester 1. Analisis ter-hadap buku teks IPA terpadu pada aspek literasi saintifik dilakukan untun setiap bab dari buku teks IPA terpadu. Proses literasi saintifik itu sendiri terdiri atas empat aspek, yaitu konteks saintifik, proses saintifik, konsep saintifik dan sikap saintifik.

Aspek pertama dari literasi saintifik adalah konteks saintifik. Konteks saintifik pada penelitian ini terdiri dari tujuh indikator. Berdasarkan penjelasan tersebut, maka indikator konteks saintifik dalam penelitian ini terdiri dari tujuh indikator. Indikator-indikator tersebut yaitu: 1) memuat fenomena ilmiah untuk menjelaskan fenomena sehari-hari; 2) memuat keterkaitan antara sains dengan fenomena seharihari; 3) mengaplikasikan sains dalam bidang kesehatan; 4) mengaplikasikan sains dalam penggunaan sumber daya alam; 5) mengaplikasikan sains dalam meningkatkan kualitas lingkungan; 6) mengaplikasikan sains untuk meminimalisir bahaya kerusakan alam; dan 7) meng-aplikasikan sains di bidang teknologi.

Berdasarkan ketujuh indikator tersebut, diperoleh hasil analisis buku teks IPA terpadu pada aspek konteks saintifik. Hasil analisis tersebut dituangkan dalam bentuk grafik. Adapun grafik tersebut dapat dilihat pada Gambar 1 .

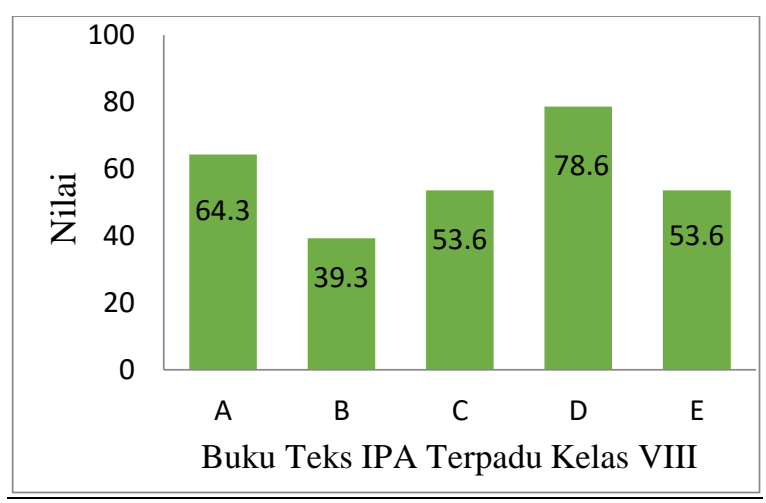

Gambar 1. Hasil Analisis Buku Teks IPA Terpadu pada Aspek Konteks Saintifik

Dari gambar 1 dapat diungkapkan bahwa dari kelima buku teks IPA terpadu yang dianalisis, diperoleh nilai aspek konteks saintifik pada buku teks $\mathrm{A}, \mathrm{B}, \mathrm{C}, \mathrm{D}$ dan $\mathrm{E}$ masing-masing sebesar 63.3, 39.3, 53.6, 78.6 dan 53.6. Ini berarti bahwa pada aspek konteks saintifik, buku yang memiliki nilai tertinggi adalah buku D yaitu 78.6 dengan kategori baik, sedangkan buku yang memiliki nilai terendah adalah buku B yaitu 39.3 dengan kategori kurang baik.

Aspek kedua dari literasi saintifik adalah proses saintifik. Proses saintifik terdiri dari delapan indikator. Kedelapan indikator tersebut ntara lain: 1) mengidentifikasi fenomena ilmiah; 2) menganalisis dan menerapkan pengetahuan ilmiah yang sesuai; 3) mengidentifikasi cara mengeksplor pertanyaan yang diberikan secara ilmiah; 4) mengevaluasi cara mengeksplorasi pertanyaan yang diberikan secara ilmiah; 5) menafsirkan data dan bukti secara ilmiah; 6) membedakan antara argumen yang didasarkan pada bukti ilmiah dan teori yang didasarkan pada pertimbangan lainnya; dan 8) menganalisis dan menginterpretasikan data serta menarik kesim pulan dengan tepat. Hasil analisis buku teks IPA terpadu pada aspek proses saintifik diperlihatkan pada Gambar 2.

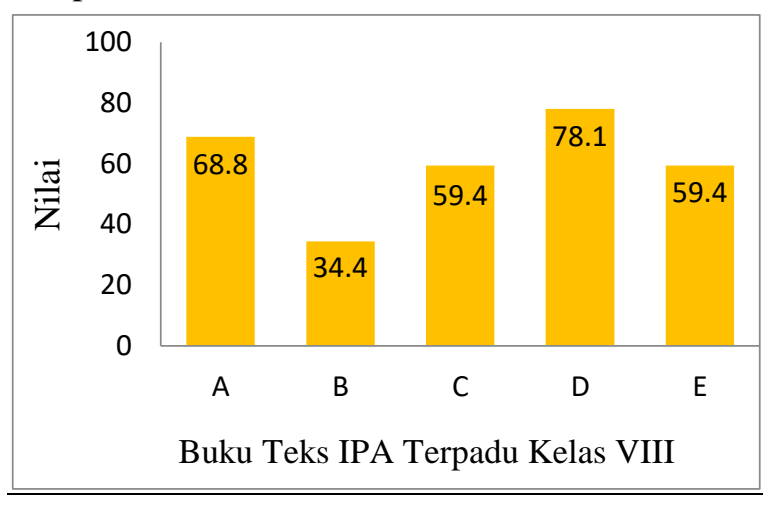

Gambar 2. Hasil Analisis Buku Teks IPA Ter padu pada Aspek Proses Saintifik

Berdasarkan Gambar 2 dapat dijelaskan bahwa nilai untuk aspek proses saintifik pada buku A, B, C, D dan E berturut-turut adalah 68.8, 34.4, 59.4, 78.1 dan 59.4. Buku yang memiliki nilai paling tinggi adalah buku D yaitu 78.1 dengan kategori baik, sedangkan buku yang memiliki nilai paling rendah adalah buku B yaitu 34.4 dengan kategori kurang baik.

Selanjunya, aspek ketiga dari literasi saintifik yaitu konsep saintifik. Aspek ini terdiri 
dari tujuh indikator. Indikator tersebut antara lain: 1) materi yang disajikan memiliki relevansi terhadap situasi kehidupan nyata; 2) memuat konsep-konsep dan teori ilmiah yang penting; 3) materi yang disajikan sesuai dengan tingkat perkembangan siswa SMP; 4) memuat sifat desain yang tepat untuk pertanyaan ilmiah; 5) memuat pengetahuan yang bersifat membangun dalam mendefinisikan ilmu pengetahuan; 6) pernyataan ilmiah didukung oleh data dan penalaran sains; dan 7) memuat peran kolaborasi dan kritik dalam membangun keyakinan akan pernyataan ilmiah. Adapun hasil analisis buku teks IPA terpadu pada aspek konsep saintifik diperlihatkan oleh Gambar 3.

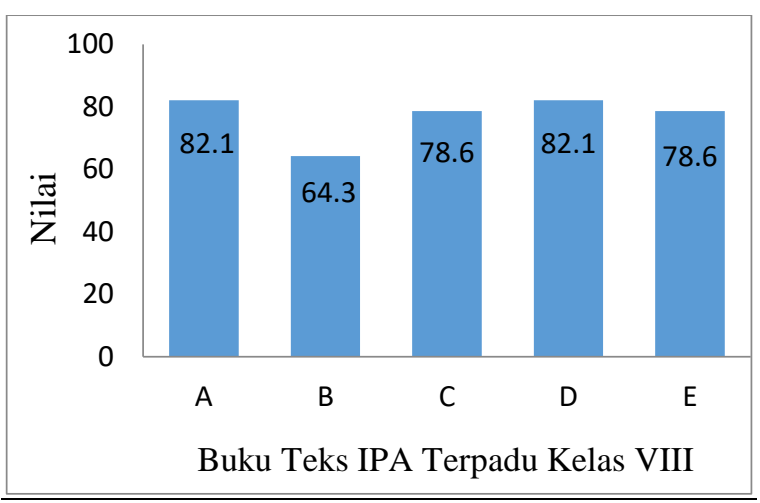

Gambar 3. Hasil Analisis Buku Teks IPA Terpadu pada Aspek Konsep Saintifik

Berdasarkan Gambar 3 dapat diketahui bahwa untuk aspek konsep saintifik diperoleh nilai masing-masing buku $\mathrm{A}, \mathrm{B}, \mathrm{C}, \mathrm{D}$ dan $\mathrm{E}$ sebesar 64.3, 39.3, 53.6, 78.6, dan 53.6. Dari gambar 3 juga dapat dilihat bahwa buku A dan D memiliki nilai paling tinggi yaitu 82.1 dengan kategori sangat baik, sedangkan buku B memiliki nilai paling rendah yaitu 64.3 dengan kategori baik.

Aspek terakhir dari literasi saintifik adalah sikap saintifik. Sikap saintifik pada penelitian ini terdiri dari enam indikator. Indikator tersebut antara lain: 1) memuat pertanyaan atau pernyataan yang dapat memicu rasa ingin tahu; 2) memuat pertanyaan atau pernyataan untuk mening-katkan minat dalam sains; 3) memuat bukti ilmiah sebagai dasar keyakinan untuk penjelasan materi; 4) memuat pendekatan ilmiah untuk penyelidikan; 5) memuat kepedulian terhadap lingkungan; dan 6) memuat arahan untuk membiasakan dan mempromosikan perilaku ramah lingkungan. Indikator-indikator tersebut diharapkan mampu mengukur sikap saintifik peserta didik. Adapun hasil analisis buku teks
IPA terpadu pada aspek sikap saintifik ditunjukkan pada Gambar 4.

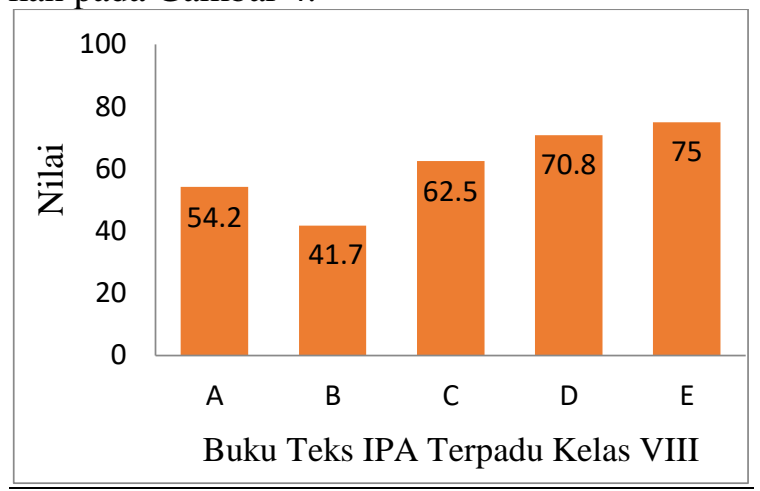

Gambar 4. Hasil Analisis Buku Teks IPA Terpadu pada Aspek Sikap Saintifik

Dari Gambar 4 dapat dijelaskan bahwa pada aspek sikap saintifik diperoleh nilai buku A, B, C, D dan E berturut-turut sebesar 54.2, 41.7, $62.5,70.8$ dan 75 . Hal ini dapat dipahami bahwa buku $\mathrm{E}$ memiliki nilai tertinggi yaitu 75 dengan kategori baik, sedangkan buku B memiliki nilai terendah yaitu 41.7 dengan kategori cukup baik.

Setelah dilakukan pengolahan data secara keseluruhan, diperoleh hasil analisis buku teks IPA terpadu kelas VIII semester 1 pada aspek literasi saintifik. Indikator literasi saintifik secara keseluturan terdiri dari: 1) konteks saintifik; 2) peoses saintifik; 3) konsep saintifik; dan 4) sikap saintifik. Data hasil analisis tersebut dapat dilihat pada Gambar 5.

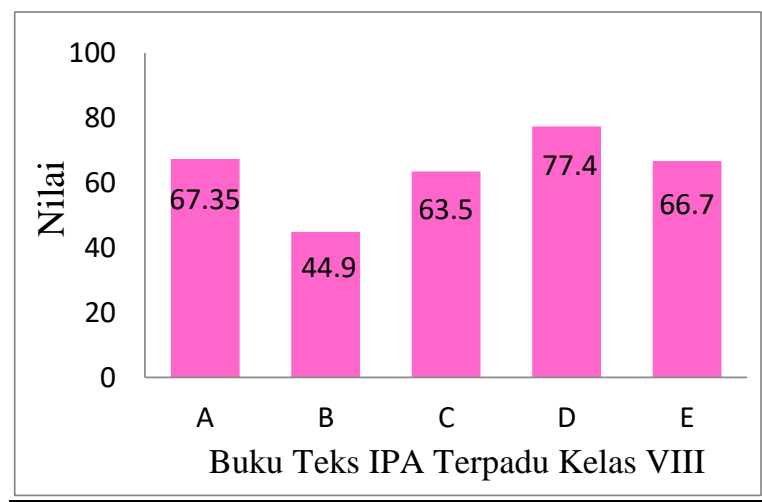

Gambar 5. Hasil Analisis Buku Teks IPA Terpadu pada Aspek Literasi Saintifik

Berdasarkan gambar 5 diketahui bahwa nilai literasi saintifik yang terdapat pada buku A, B, C, D dan E masing-masing sebesar 67.35, 44.9, 63.5, 77.4 dan 66.7. Hal ini dapat diartikan bahwa buku teks IPA terpadu yang memiliki nilai tertinggi ditinjau dari literasi saintifik adalah buku D yaitu 77.4 dengan kategori baik, sedangkan nilai terendah adalah buku B yaitu 44.9 dengan kategori cukup baik. 


\section{Pembahasan}

Hasil penelitian ini dapat dijadikan sebagai bahan pertimbangan dalam memilih buku teks IPA terpadu yang paling cocok digunakan untuk pembelajaran di kelas VIII semester 1, dalam rangka meningkatkan kemampuan literasi saintifik peserta didik. Selain itu, penelitian ini juga dapat dijadikan sebagai bahan pertimbangan bagi penelitian selanjutnya terkait pengembangan buku teks IPA terpadu bermuatan literasi saintifik. Dengan adanya penelitian ini, pendidik dan peserta didik diharapkan mampu memilih buku teks yang paling baik untuk meningkatkan kemampuan literasi saintifik peserta didik.

Berdasarkan hasil penelitian pada gambar 1 dan gambar 2, diperoleh bahwa buku A dan buku D dapat dikategorikan baik pada aspek konteks dan proses saintifik. Disisi lain buku C dan E dapat dikategorikan cukup baik sedangkan buku B dengan kategori kurang baik. Ini berarti bahwa dari segi konteks saintifik dan proses saintifik, buku teks IPA terpadu yang baik digunakan adalah buku A dan buku D. Hal ini sesuai dengan kategori tingkat literasi saintifik yang ditampilkan pada Tabel 1 (Riduwan, 2012), dimana untuk buku yang memiliki nilai pada rentang 0-20 dapat dikategorikan tidak baik, 21-40 dikategorikan kurang baik dan 4160 dikategorikan cukup baik. Sementara itu, untuk nilai 61-80 dikategorikan baik dan nilai 81-100 dikategorikan sangat baik. Begitupula untuk hasil penelitian pada gambar 3, gambar 4 dan gambar 5. Hasil dari penelitian ini dikategorikan berdasarkan Tabel 1.

Berdasarkan hasil penelitian yang ditampilkan pada gambar 3, buku A dan buku D dapat dikategorikan sangat baik berdasarkan aspek konsep saintifiknya. Buku B, C dan buku E dapat dikategorikan baik. Hal ini berarti bahwa buku teks IPA terpadu yang paling baik digunakan dilihat dari aspek konsep saintifik adalah buku A dan buku D.

Selanjutnya, hasil yang ditunjukkan pada gambar 4 adalah penilaian berdasarkan aspek sikap saintifik. Pada aspek ini buku C, D dan E dapat dinyatakan baik, sedangkan buku A dan B dinyatakan cukup baik. Hal ini dapat dipahami bahwa buku teks IPA terpadu yang baik digunakan dalam pembelajaran dilihat dari aspek sikap saintifik adalah buku C, D dan E.

Secara keseluruhan, berdasarkan gambar 5, buku A, C, D dan E dapat dikategorikan baik karena memuat hampir $78 \%$ dari keseluruhan indikator literasi saintifik. Sedangkan buku B dapat dikategorikan cukup baik karena hanya memuat $45 \%$ dari keseluruhan indikator literasi saintifik. Berdasarkan hal ini pendidik diharapkan mampu mengarahkan peserta didik untuk memilih dan menggunakan buku teks IPA terpadu yang memiliki kategori baik, sehingga dapat digunakan dalam proses pembelajaran.

Penelitian mengenai analisis buku teks ditinjau dari aspek literasi saintifik ini sebelumnya sudah pernah dilakukan oleh Nasution, et al (2018) berupa analisis literasi saintifik pada sebuah buku ajar. Selain itu, Kurnia, et al (2014) juga pernah melakukan penelitian tentang analisis bahan ajar berdasarkan literasi saintifik. Namun hasil dari kedua penelitian tersebut menunjukkan bahwa aspek konteks tidak ditemukan pada kedua buku yang telah dianalis.

Berpijak dari hal tersebut, penelitian ini dilakukan untuk mengetahui ruang lingkup literasi saintifik berdasarkan kerangka PISA (2015) pada buku teks IPA Terpadu kelas VIII Semester 1 terkait keempat aspek literasi saintifik tersebut. Ini berarti empat aspek dari literasi saintifik dikaji secara keseluruhan. Lain halnya dengan penelitian relevan yang hanya mengkaji dua atau tiga aspek literasi saintifik, dari empat aspek yang ada. Karena mengkaji keseluruhan dari aspek literasi saintifik, berarti hasil yang diperoleh pada penelitian ini juga menyeluruh, sehingga menghasilkan kesimpulan yang lebih akurat.

\section{KESIMPULAN}

Dari analisis data yang telah dilakukan, diperoleh kesimpulan bahwa dari lima buku teks IPA terpadu yang dianalisis, buku yang paling baik digunakan untuk meningkatkan kemampuan literasi saintifik peserta didik adalah buku D dengan nilai 77.4. Secara berturut-turut buku yang baik digunakan berdasarkan literasi saintifik adalah buku D, A, E, C dan buku B dengan nilai masaing-masing sebesar 77.4, 67.35, 66.7, 63.5 dan 44.9. Adanya buku teks IPA terpadu yang memuat literasi saintifik ini hendaknya mampu meningkatkan kemampuan literasi saintifik peserta didik di Indonesia.

\section{DAFTAR PUSTAKA}

Anjarsari, P. (2014). Literasi Sains dalam Kurikulum dan Pembelajaran IPA SMP. Prosiding Semnas Pensa VI "Peran Lit- 
erasi Sains". Surabaya. 20 Desember 2014.

Asrizal., Amran, A., Ananda, A., Festiyed., \& Sumarmin, R. (2018). The Development of Integrated Science Instructional Material to Improve Students Digital Literacy in Scientific Approach. Jurnal Pendidikan Indonesia. 7: 442-450.

Asrizal., Festiyed., \& Sumarmin, R. (2017). Analisis Kebutuhan Pengembangan Bahan Ajar IPA Terpadu Bermuatan Literasi Era Digital untuk Pembelajaran Siswa SMP Kelas VIII. Jurnal Eksakta Pendidikan. 1: 1-8.

Azhar, A. (2003). Media Pembelajaran. Jakarta: Raja Grafindo Persada.

Chiapetta, E. L., Fillman, D. A \& Sethna, G. H. (1991). A Method to Quantify Major Themes of Scientific Literacy in Science Textbooks. Journal of research in science teaching. 28 (8): 713-725.

DeBoer, G. E. (2000). Scientific Literacy: Another Look at Its Historical and Contemporary Meanings and Its Relationship to Science Education Reform. Journal of Research In Science Teaching.

Fatmawati, I. N \& Utari, S. (2015). Penerapan Level of Inquiry untuk Meningkatkan Literasi Sains Siswa SMP Tema Limbah dan Upaya Penanggulangannya. Edusains. 7: 151-159.

Festiyed. (2014, Mei). Pengembangan Generic Life Skill Siswa Menengah Pertama pada Pembelajaran Fisika. Seminar Nasional dan Rapat Tahunan Bidang MIPA. Bogor: IPB.

Festiyed. (2015). Penerapan CD Pembelajaran IPA Berbasis Siklus Belajar 5E terhadap Kompetensi Peserta Didik Kelas VIII SMP Negeri 2 Padang. Pillar of Physics Education, 6: 49-56.

Kurnia, F., Zulherman. \& Fathurohman, A. (2014) Analisis Bahan Ajar Fisika SMA kelas XI di Kecamatan IndralayaUutara berdasarkan Kategori Literasi Sains. Jurnal inovasi dan pembelajaran fisika. 1: 43-47.

Nasution, M., Sipahutar, H., \& Harahap, F. (2018). Analisis Ruang Lingkup Literasi Sains Buku Ajar Biologi SMA Kelas X di Kota Binjai. Prosiding Semnas "Biologi dan Pembelajarannya". Surabaya, 20 Desember 2014.
NRC (National Research Council). (1996). National Science Education Standards. Washington, DC: National Academy Press.

Nofiana, M. \& Julianto, T. (2017). Profil Kemampuan Literasi Sains Siswa SMP di Kota Purwokerto Ditinjau dari Aspek Konten, Proses, dan Konteks Sains. Jurnal Sains Sosial dan Humaniora. 1: 77-84.

Nugroho, E. D. Vlorensius., Rasidah, L. H., \& Anisa, N. (2017). Analisis Isi, Penyajian Materi dan Keterbacaan dalam Buku Teks IPA Kurikulum 2013 SMP Kelas VII Semester 1. Jurnal Pendidikan Biologi Indonesia. 3: 114-122.

OECD. (2015). PISA 2015 Draft Mathematic Framework. New York: Columbia University.

OECD. (2016). PISA 2015 Result in Focus. New York: Columbia University.

Retno, A. T. P., Saputro, S. \& Ulfa, M. (2017). Kajian Aspek Literasi Sains pada Buku Ajar Kimia SMA Kelas XI di Kabupaten Brebes. Prosiding Seminar Nasional dan Pendidikan Sains. Surakarta, 26 Oktober 2017.

Riduwan. (2012). Skala Pengukuran Variabelvariabel Penelitian. Bandung: Alfabeta.

RTI International. (2014). Prioritizing Reform, Innovation, and Opportunities for Reaching Indonesia's Teachers, Administrators, and Students. Pembelajaran Literasi Kelas Awal SD/MI di LPTK. United States Agency for International Development (USAID).

Rusilowati, A. (2014). Analisis Buku Ajar IPA yang digunakan di Semarang Berdasarkan Muatan Literasi Sains. Prosiding Semnas "konservasi dan kualitas pendidikan". Semarang 2014.

Suastra, I. W. (2010). Model Pembelajaran Sains Berbasis Budaya Lokal untuk Mengembangkan Kompetensi Dasar Sains dan Nilai Kearifan Lokal di SMP. Jurnal Pendidikan dan Pengajaran IKIP Negeri Singaraja. 2: 8-16.

Tarigan, H. G dan Djago. T. (2009). Telaah Buku Teks Bahasa Indonesia. Bandung: Angkasa.

Toharudin, U. (2011). Membangun Literasi Sains Peserta Didik. Bandung: Humaniora.

Wulandari, N., \& Sholihin, H. (2015). Penerapan Model Problem Based Learning (PBL) pada Pembelajaran IPA Terpadu 
untuk Meningkatkan Aspek Sikap Literasi Sains Siswa SMP. Prosiding Simposium
Nasional Inovasi dan Pembelajaran Sains.

Bandung, 8-9 Juni 2015. 